\title{
APLIKASI AKAD WAKALAH DALAM LETTER OF CREDIT BANK SYARIAH MANDIRI
}

\author{
Irwan Maulana \\ STAI Asy-Syukriyyah Tangerang \\ irwan.maulana@asy-syukriyyah.ac.id
}

\begin{abstract}
Literally, Wakalah is a guarding, holding back or the application of expertise on behalf of others. Means pointing someone to take over something, to delegate any assignment to someone else. Wakalah is also a responsibility therefore, a representative must do the seponsibility as someone who is trusted to carry out their responsibilities faithfully. If wages are required for the recipient of authority in the authorization transaction, the case recipient is entitled to his salary after fulfilling his duties. If payment of wages is not required in the transaction, then his service is only good and he has no right to ask for payment. According to Islamic law, a contract must fulfill the main components. Without these main components, no transaction will be occurred. Components in the contract must be present aqid, ma'qud alaih, mawdu al aqd, and also Shighah. Aqid in this case are importers, exporters,opening banks and advising banks. The object of the L/C transaction must be useful and not prohibited by Islamic law. Therefore, if the object is banned by the Sharia such as drugs, alcohol,then this L/C will automatically be invalid.
\end{abstract}

Keyword: Wakalah, Letter of Credit, Export, Import

\section{PENDAHULUAN}

Akad wakalah merupakan salah satu akad yang dikembangkan dalam transaksi keuangan kontemporer, baik sebagai akad yang mandiri maupun dikombinasikan dengan akad lain (misal akad murabahah). Dari perspektif praktik hukum, akad wakalah yang mandiri adalah pemberian kuasa dari pihak yang berperkara kepada advokat atau penasihat hukum untuk mewakilinya dalam sidang di pengadilan ${ }^{1}$.

Dalam Hadist Nabi Muhammad SAW yang diriwayatkan oleh Imam Bukhari dan Abu Hurairah bahwa ada seorang laki-laki datang kepada Nabi SAW untuk menagih hutang kepada beliau dengan cara kasar, sehingga para sahabat berniat untuk "menanganinya". Beliau bersabda, 'Biarkan ia, sebab pemilik hak berhak untuk berbicara;' lalu sabdanya, 'Berikanlah (bayarkanlah) kepada orang ini unta umur setahun seperti untanya (yang dihutang itu)'. Mereka menjawab, 'Kami tidak mendapatkannya kecuali yang lebih tua.' Rasulullah kemudian bersabda: 'Berikanlah kepadanya. Sesungguhnya orang yang paling baik di antara kalian adalah orang yang paling baik di dalam membayar."

\footnotetext{
${ }^{1}$ Jaih Mubarok, 2017. Fikih Mu"amalah Maliyyah Akad Tabarru", (Simbiosa Rekatama Media) h. 165
} 
Dalam hadist yang diriwayatkan Malik dalam kitab al-Muwaththa bahwa Rasulullah SAW mewakilkan kepada Abu Rafi' dan seorang Anshar untuk mengawinkan (qabul perkawinan Nabi dengan) Maimunah r.a."

Berdasarkan dalil-dalil yang ada, Jumhur ulama sepakat membolehkan akad wakalah atas pekerjaan/muamalah yang berkaitan dengan harta, baik untuk menerima (al-qabdh diantaranya menerima haiah) maupun untuk menyerahkannya (al-ikhraf). Akad wakalah untuk menerima atau mengeluarkan zakat, kifarat, nadzar, sedekah, haji/umrah (jika lemah atau sudah meninggal), menyembelih hewan kurban dan/atau hewan sebagai dam (denda dalam haji) adalah boleh.

Dalam mengikuti perkembangan zaman, aspek muamalah dalam penerapan syariah haruslah dinamis dalam menyesuaikan kebutuhan yang selalu berubah dan beragam caranya. Di Indonesia, melalui Dewan syariah nasional majelis ulama Indonesia (DSN-MUI) menetapkan hukum ataupun fatwa mengenai wakalah, yaitu fatwa DSN-MUI nomor 10 tahun 2000 tentang wakalah dan fatwa DSN-MUI nomor 52 tahun 2006 tentang wakalah bil ujrah pada asuransi syariah dan reansurasi syariah. Disamping itu, terdapat pula fatwa yang secara tidak langsung berkaitan dengan wakalah bil ujrah, yaitu fatwa DSN- MUI nomor 59 tahun 2014 tentang keperantaraan (wasathah) dalam bisnis property.

Letter of credit disebut juga L/C, LC atau LOC dalam perbankan konvesional mengakomodir kebutuhan pengusaha/ ekportir menerima pembayaran tanpa menunggu berita dari luar negeri setelah barang dan berkas dokumen dikirimkan ke luar negeri atau kepada pemesan. Menurut Bank Indonesia LC adalah janji dari issuing bank untuk membayar sejumlah uang kepada eksportir sepanjang ia mampu untuk memenuhi syarat dan kondisi Letter of Credit tersebut.

\section{KAJIAN TEORI}

\section{Pengertian, Rukun dan Jenis Wakalah}

Wakalah diucapkan dalam dua bentuk: wakalah dan wikalah. Secara bahasa, wakalah memiliki dua arti: al-fizh (perlindungan/ melindungi) dan al-tafwidh (penyerahan/ menyerahkan $)^{2}$. Selain di artikan secara bahasa (etimologis), kata wakalah juga diartikan secara istilah (terminologi) oleh ulama dengan penjelasan yang beragam. Secara umum, keragaman tersebut dapat di kelompokan menjadi dua pendapat ulama Hanafiah dan Syafi'iah ${ }^{3}$. Dalam pandangan ulama Hanafiah, sebagaimana yang tercantum dalam kitab Takmilah Fath al-Qadir (6/3), al-Bada"i al-Shana"i (6/19), Radd al-Muhtar (4/417), dan Tabyin al-Haqa "iq (4/254), dijelaskan bahwa wakalah secara istilah adalah:"Wakalah adalah perbuatan hukum seseorang

\footnotetext{
${ }^{2}$ Ibid.

${ }^{3}$ Taqiy al-Din Abi Bakr Ibn Muhammad al-Husaini, Kiyafat al-Akhyar fi Hill Ghayat al-Ikhtishar (Semarang: Taha Putra, t.th), vol. I, h. 283
} 
dalam rangka menempatkan pihak lain pada posisi dirinya untuk melakukan perbuatan hukum tertentu yang boleh dan di ketahui (tidak gharar)'”.

Sementara Dalam pandangan Syafi'iah, sebagaimana tercantum dalam kitab Mughni alMuhtaj (2/217), dijelaskan bahwa yang di maksud wakalah secara istilah ialah: "Wakalah adalah penyerahan kewenangan atas apa yang boleh di lakukanya sendiri, (perbuatan tersebut termasuk perbuatan) yang boleh dikuasakan oleh pihak lain untuk melakukannya selama pemilik kewenangan (mewakili) masih hidup".

Wakalah adalah pelimpahan kekuasaan oleh seseorang kepada yang lain dalam hal-hal yang diwakilkan ${ }^{4}$. Wakalah merupakan akad antara dua pihak yang mana pihak satu menyerahkan, mendelegasikan, mewakilkan, atau memberikan mandat kepada pihak lain, dan pihak lain menjalankan amanat sesuai permintaan pihak yang mewakilkan ${ }^{5}$.

Adapun rukun dan syarat akad wakalah:

1) Adanya pihak yang mewakilkan (Al-Muwakkil)

Rukun dan syarat sahnya suatu perjanjian dengan skema wakalah tentu adanya pihak yang mewakilkan atau pihak pemberi kuasa. Tak sekadar itu saja, dalam memberikan kuasa, pihak yang memberi kuasa pun harus memenuhi setidaknya dua syarat;

Pertama, pihak yang mewakilkan memiliki hak untuk bertindak pada bidang-bidang yang didelegasikan. Sebab, tidak akan sah jika seseorang mewakilkan sesuatu yang bukan haknya. Kedua, pihak pemberi kuasa memiliki hak atas sesuatu yang dikuasakannya dan cakap secara hukum. Artinya, pihak yang memberi kuasa atau yang mewakilkan adalah orang yang telah dewasa dan sehat akalnya.

2) Ada pihak yang diwakilkan (Al-Wakil)

Adanya pihak yang menerima kuasa menjadi rukun dan syarat sahnya akad wakalah lainnya. Penerima kuasa haruslah seseorang atau badan usaha yang harus cakap hukum dan memiliki pemahaman yang baik terkait dengan aturan-aturan yang mengatur proses akad tersebut. Selain itu, penerima kuasa juga harus memiliki kemampuan untuk menjalankan mandat atau amanah yang diberikan oleh pihak pemberi kuasa.

3) Ada objek yang diwakilkan

Selain para pihak yang terlibat, rukun dan syarat sahnya akad wakalah juga mencakup adanya objek yang diwakilkan. Objek ini haruslah sesuatu yang bisa diwakilkan kepada orang lain, seperti jual beli, sewa-menyewa, dan lainnya yang memang berada dalam kekuasaan pihak yang memberikan kuasa. Selain itu, objek yang diwakilkan tidak boleh bertentangan dengan syariat Islam.

\footnotetext{
${ }^{4}$ M. Syafii Antonio, 2001. Bank Syariah: Dari Teori ke Praktik, (Gema Insani Pers, Jakarta) h. 120.

${ }^{5}$ Ismail. 2011. Perbankan Syariah (Kencana Prenada Media Group, Jakarta) h. 194.
} 
Adapun Ketentuan mengenai pekerjaan dalam wakalah sebagai berikut:

1. Pekerjaan yang diwakilkan merupakan pekerjaan yang boleh dikerjakan oleh pihak yang mewakilkan karena dalam teori pelimpahan (al-tafwidh/pemberian kuasa), akad wakalah merupakan akad yang menempatkan pihak wakil pada posisi muwakkil.

2. Pekerjaan yang di wakilkan merupakan pekerjaan yang diketahui (kualitas dan kuantitasnya agar terhindar dari gharar (katsir), sebagaimana disyaratkan ulama syafi'ah.

3. Pekerjaan yang diwakilkan tidak boleh berupa permohonan pembiayaan (pengajuan pinjaman) qardh kepada pihak lain. Apabila hal tersebut dilakukan, kewajiban membayar utanng qardh merupakan kewajiban wakil (bukan kewajiban pihak yang mewakilkan), kecuali permohonannya dilakukan secara tertulis.

4. Pekerjaan yang dilakukan merupakan pekerjaan yang boleh diwakilkan secara syariah. Karena tidak sah akad wakalah atas:

a. Pekerjaan yang termasuk ibadah fisik mahdhah (shalat, puasa, bercuci [al-tharah]), karena tujuannya adalah untuk menguji ketaatan ketundukan hamba-Nya (al-ibtila "wa al-ikhtibar) yang tidak akan tercapai, kecuali dilakukannya sendiri.

b. Pekerjaan yang tujuannya untuk membuktikan kebenaran diantaranya akad wakalah untuk bersumpah tidaklah sah (al-yamin) dan saksi langsu ng yang melihatnya karena sumpah merupakan counter atas bukti (al- bayinat) gugatan yang dilakukan sumpah diwajibkan kepada tergugat.

c. Pekerjaan yang menyalahi hukum dan kehormatan. Akad wakalah untuk bersetubuh (jima") tidak sah karena merupakan pekerjaan yang tujuannya menjaga kehormatan/kesucian (al-iffah) dan berdampak pada lahirnya anak yang nasab-nya di nisbah-kan kepada pelaku (hak kewalian dan waris).

\section{Jenis-Jenis Akad Wakalah}

1. Wakalah al- Mutlaqah, yakni mewakilkan secara mutlak, tanpa batas waktu dan untuk segala urusan. Dalam hukum positif, sering dikenal dengan istilah kuasa luas, yang biasanya digunakan untuk mewakili segala kebutuhan pemberi kuasa dan biasanya hanya untuk perbuatan pengurusan (beheren).

2. Wakalah al- Muqayyadah, yakni penunjukan wakil untuk bertindak atas nama dalam urusan-urusan tertentu. Dalam hukum positif, hal ini dikenal sebagai kuasa khusus dan biasanya hanya untuk satu perbuatan hukum. Kuasa khusus ini biasanya diperuntukan bagi perbuatan hukum tertentu yang berkaitan dengan kepemilikan atas suatu barang, membuat perdamaian, atau perbuatan lain yang hanya bisa dilaksanakan oleh pemilik barang.

3. Wakalah al-Amamah, yakni perwakilan yang lebih luas dari al- muqayyadah tetapi lebih 
sederhana daripada al-mutlaqah. Biasanya kuasa ini untuk perbuatan pengurus sehari-hari. Dalam praktek perbankan syariah, wakalah ini sering sekali digunakan sebagai pelengkap transaksi suatu akad atau sebagai jembatan atas keterbatasan ataupun hambatan dari pelaksanaan suatu akad ${ }^{6}$.

Dalam skema al-Wakalah akan lebih jelas diketahui posisi bank syariah dan nasabah pengguna jasa bank syariah. Bank syariah (wakil) mendapat kuasa dari nasabah (muwakil) untuk melakukan tugas atas nama pemberi kuasa.

\section{Skema Wakalah}

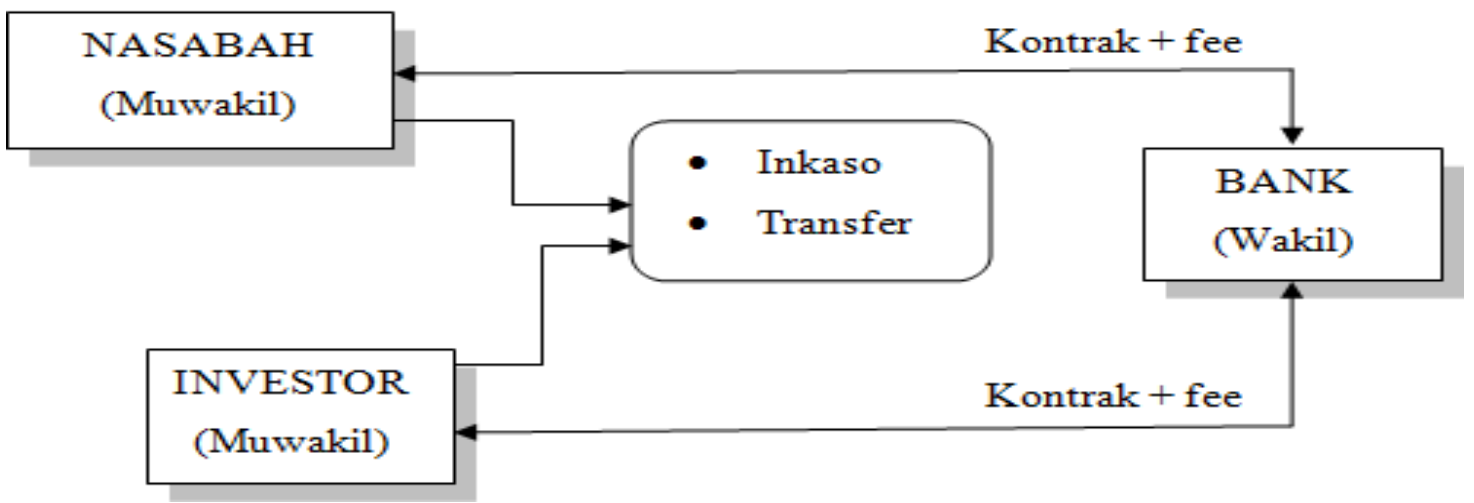

\section{Skema Akad Wakalah ${ }^{7}$}

Contoh studi kasus pada PT. Priyatama Perkasa adalah perusahaan importir ikan hias. PT Priyatama Perkasa melakukan pemesanan 1 kontainer ikan hias hidup dari Australian Maline Co.Ltd. Pihak Australia yang baru akan menyetujui menyerahkan 1 wadah ikan hias tersebut, yang disetujui PT Priyatama Perkasa diterbitkan L/C dari Bank yang dipercaya. PT. Priyatama Perkasa kemudian meminta Bank Syariah untuk menerbitkan L/C dengan memberikan jaminan pembayaran tanah milik PT yang menyediakan di daerah Parung.

Dalam kasus tersebut, maka Bank Syariah dapat menggunakan bentuk akad wakalah bil ujrah. PT. Priyatama Perkasa memberikan kuasa (wakalah) kepada Bank Syariah untuk meminta perwakilan selaku dan memberikan jaminan atas pemenuhan kewajiban pembayaran PT. Priyatama Perkasa atas pembayaran pemesanan ikan hias yang diajukan kepada Australian Marine Co.Ltd. Karena hal tersebut, Bank Syariah berhak untuk mendapatkan fee (ujrah) sesuai ketentuan. Dalam hal ini, Bank Syariah hanya mengeluarkan mata uang sebagai wakil dari dana (dengan akad wakalah bil ujrah tersebut), maka nasabah tersebut harus memiliki dana pada Bank Syariah tersebut, yang sama besarnya dengan jumlah tagihan yang harus dipenuhi. Berikut adalah skema dari wakalah bil ujrah:

\footnotetext{
${ }^{6}$ Irma Devita Purnamasari dan Suswinarno. 2011. Akad Syariah, (Bandung: PT Mizan Pustaka) h. 146-147.

${ }^{7}$ Ismail, 2011. Perbankan Syariah. (Kencana Prenada Media Group, Jakarta) h. 194-195
} 


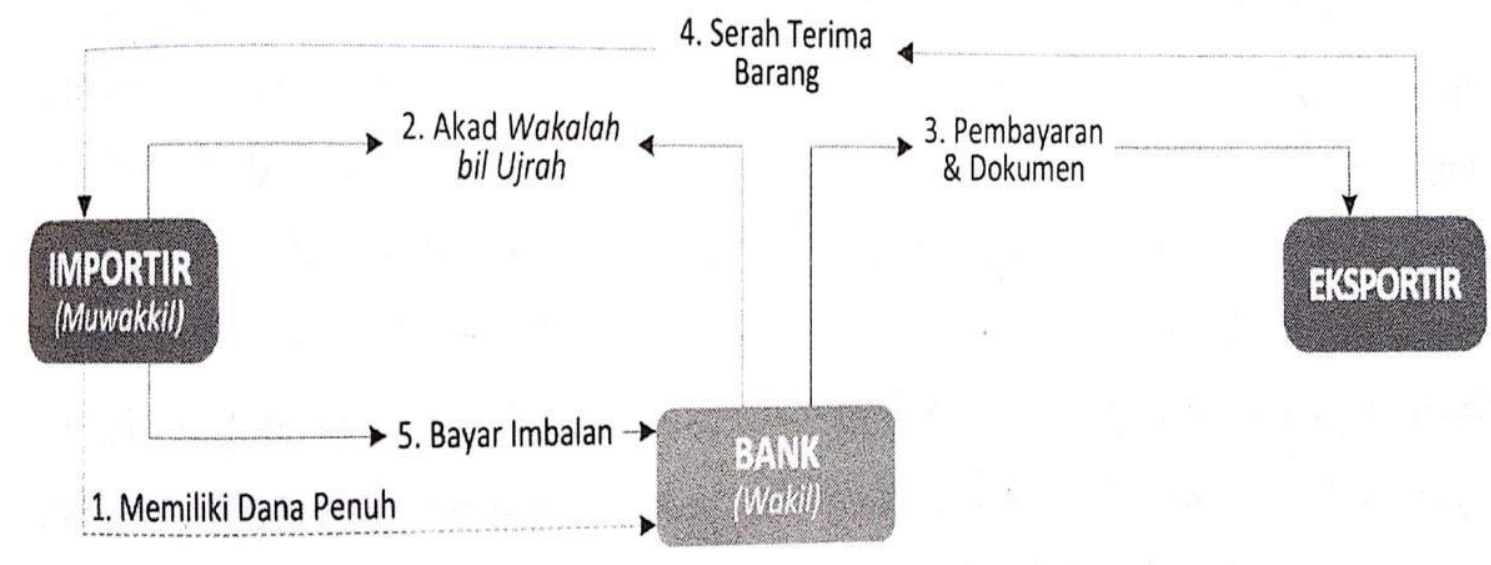

Keterangan:

1) Importir dalam kasus ini PT.Priyatama Perkasa memiliki dana penuh.

2) Bank dan PT.Priyatama Perkasa melakukan akad wakalah bil ujrah.

3) Bank melakukan pembayaran dan pemberian dokumen kepada Eksportir (Australian Marine Corp.Ltd) .

4) Australian Marine Corp.Ltd memberikan barang kepada importir.

5) PT.Priyatama Perkasa membayar imbalan kepada Bank.

Adapun bila nasabah tidak memiliki dana yang sama jumlahnya dengan tagihan yang harus dipenuhinya, maka antara Bank Syariah dengan PT.Priyatama Perkasa terjadi akad wakalah bil ujrah dan qardh. Dimana Bank Syariah memberikan pinjaman bagi PT.Priyatama Perkasa dengan menggunakan akad qardh dengan tidak mendapatkan imbalan atas pinjaman yang diberikan tersebut. Bank kemudian menggunakan akad wakalah bil ujrah dalam rangka pengurusan dokumen transaksi impor. 


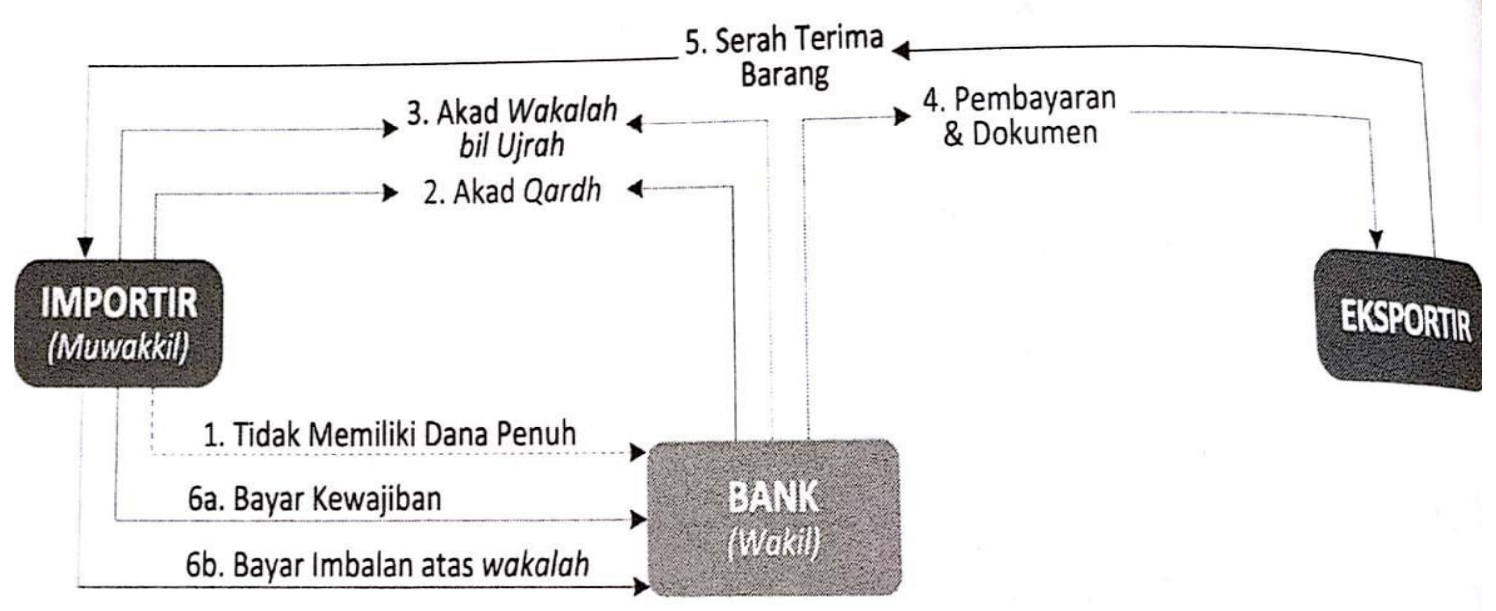

Keterangan:

1. Importir (PT.Priyatama Perkasa) tidak memiliki dana yang penuh.

2. Bank Syariah dan Importir melakukan akad qardh.

3. Bank Syariah dan Importir melakukan akad wakalah bil ujrah.

4. Bank Syariah melakukan pembayaran dan dokumen kepada eksportir .

5. Eksportir menyerahkan barang kepada importir.

6. a. Importir membayar kewajiban atas qardh kepada Bank Syariah.

b. Importir membayar imbalan atas wakalah kepada Bank Syariah.

\section{Pengertian Letter of Credit (L/C)}

Letter of Credit (L/C) Impor Syariah menurut Dewan Syariah Nasional yang tertera dalam kitab Fatwa MUI Nomor 34 yaitu surat pernyataan akan membayar kepada eksportir yang diterbitkan oleh bank untuk kepentingan importir dengan pemenuhan persyaratan tertentu sesuai dengan prinsip syariah. Letter of Credit $(L C)$ Ekspor Syariah menurut Dewan Syariah Nasional yang tertera dalam kitab Fatwa MUI Nomor 35 yaitu surat pernyataan akan membayar kepada eksportir yang diterbitkan oleh bank untuk memfasilitasi perdagangan ekspor dengan pemenuhan persyaratan tertentu sesuai dengan prinsip syariah ${ }^{8}$. Dalam publikasi Internasional Chamber of

Commerce (ICC) dinyatakan bahwa Letter of Credit (L/C) adalah perjanjian tertulis disebuah bank yang diberikan kepada penjual atas permintaannya dan sesuai dengan instruksi-

${ }^{8}$ Fatwa Dewan Syariah Nasional, Nomor: 34 dan 35, 5-11. 
instruksi pembeli untuk melakukan pembayaran yakni dengan cara membayar, mengakses dan negosiasi yang ditentukan dan atas dokumen-dokumen yang ditetapkan9. Letter of Credit (L/C) adalah surat yang dikeluarkan oleh bank devisa atas permintaan importir (nasabah bank yang bersangkutan) dan ditujukan kepada eksportir di luar negeri yang menjadi relasi dan importir tersebut10. Atau L/C adalah janji tertulis dengan bank penerbit untuk membayar uang kepada penerima sepanjang dipenuhi persyaratan $\mathrm{L} / \mathrm{C}^{11}$.

Dasar pengaturan transaksi perdagangan internasional dengan menggunakan letter of credit adalah Uniform Custom and Practice for Documentary Credits (UCP-DC 600). UCPDC 600 adalah dasar hukum pengaturan pembayaran menggunakan Letter of Credit $(L / C)$ atau seperangkat aturan yang berlaku untuk kredit berdokumen. Dalam UCP-DC 600 tersebut tidak hanya mengatur mengenai aturan-aturan baku dan mekanisme pelaksanaan Letter of Credit $(L / C)$, akan tetapi juga mengantisipasi apabila terjadi penyimpangan dalam pelaksanaannya yang mungkin saja terjadi karena kesengajaan atau kelalaian para pihaknya ${ }^{12}$.

\section{METODE PENELITIAN}

Tulisan ini merupakan hasil penelitian kepustakaan (library research). Jenis penelitian kepustakaan merupakan penelitian yang mengandalkan data-data yang hampir sepenuhnya dari kepustakaan atau literatur, baik itu dalam bentuk fisik maupun digital. Penelitian ini lebih popular dikenal dengan penelitian kualitatif deskriptif kepustakaan atau penelitian bibliografis, dan juga dapat diistilahkan Non Reaktif yang sepenuhnya menggunakan data-data yang bersifat teoritis dan dokumentasi yang ada di perpustakaan. Peneliti memperoleh data dari hasil studi kepustakaan dari berbagai literatur buku, jurnal, karya ilmiah, dan juga dokumen-dokumen lain yang mengkaji terkait Aplikasi Akad Wakalah dalam Letter Of Credit Bank Syariah Mandiri.

\section{PEMBAHASAN}

\section{Aplikasi Pembiayaan Ekspor Impor Melalui Letter Of Credit (L/C) Menggunakan Akad Wakalah}

\section{A. Ruang Lingkup Letter of Credit (L/C)}

a. Pihak-Pihak dalam Letter of Credit $(L / C)$

Dalam bentuknya yang paling sederhana di dalam credit opening itu terdapat tiga pihak

\footnotetext{
${ }^{9}$ Heni Purwati. 2009. Skripsi: “Aplikasi Pembiayaan Ekspor Impor Melalui Letter of Credit (L/C) di Bank Mandiri Syariah Dalam Perspektif Islam”, (Surabaya: IAIN Sunan Ampel,), h. 36

${ }^{10}$ Amir M.S, Letter of Credit dalam Bisnis Ekspor Import, h.1.

${ }^{11}$ Ramlan Ginting, Letter of Credit Majalah Aspek Hukum dan Bisnis. h. 180.

12 Selfia Anggraeni, Skripsi: "Implementasi Dewan Syariah Nasional No.34 dan No.35 Tentang Letter of Credit Impor Ekspor Syariah di Bank Mu"amalat Cabang Sungkono Surabaya”, (Surabaya: IAIN Ponorogo, 2017), h. 34.
} 
yaitu: bank, pembeli, dan penjual ${ }^{13}$. Bank adalah pihak yang membuka kredit, sedangkan pembeli adalah pihak yang menyuruh membuka kredit dan penjual adalah pihak untuk kepentingan siapa kredit opening itu diberikan. Dengan adanya 3 pihak yang bersangkutan di dalam suatu pembukaan kredit, maka berarti juga terdapat perjanjian di dalam suatu pembukaan kredit, yaitu hubungan hukum antara pembeli dan bank, dan penjual serta bank dan penjual.

Dari penjelasan di atas dapat dirinci para pihak yang terkait dalam Letter of Credit:

1. Opener (importir) adalah pembeli yang membuka L/C.

2. Issue adalah bank yang mengeluarkan $\mathrm{L} / \mathrm{C}$.

3. Beneficiary adalah acreditte penjual (eksportir). ${ }^{14}$

Adapun dalam literasi lain pihak-pihak yang terkait dalam Letter of Credit adalah sebagai berikut $^{15}$ :

1. Applicant atau opener (Pembeli) yaitu importir yang meminta bantuan bank devisanya untuk membuka letter of credit guna keperluan penjual atau eksportir.

2. Beneficiary (Penjual) adalah pihak yang berhak menerima pembayaran atas sebuah letter of credit 16

3. Issuing bank atau opening bank (Bank pembuka) yaitu bank devisa yang dimintai bantuan oleh importir untuk membuka suatu letter of credit untuk keperluan eksportir. Bank devisa inilah yang memberikan jaminan kepada eksportir.

4. Advising bank (Bank Penerus) adalah bank yang menerima letter of credit sekaligus menyampaikannya kepada pihak penerima letter of credit (seller)17.

5. Confirming bank (Bank yang menjamin pembayaran) adalah bank kedua, biasanya bertindak sebagai bank yang akan melakukan pembayaran apabila importer atau opening bank tidak membayar beneficiary.

6. Paying bank (Bank pembayar) adalah bank yang namanya tertera dalam L/C sebagai pihak yang akan melakukan pembayaran kepada beneficiary.

7. Negotiating bank (Bank yang menegosiasi) adalah bank yang menyetujui untuk membeli wessel (draft) dari beneficiary, dan namanya tidak tertulis dalam letter of credit $^{18}$.

Menurut hukum Islam, sebuah kontrak harus memenuhi komponen- komponen utama

\footnotetext{
${ }^{13}$ Ramlan Ginting, Letter of Credit Majalah Aspek Hukum dan Bisnis, h.39.

${ }^{14}$ Nopirin, Ph.D, Ekonomi Internasional, h.235.

15 Selfia Anggraeni. 2017. Skripsi: "Implementasi Fatwa Dewan Syariah Nasional No.34 dan No.35 Tentang Letter of Credit Impor-Ekspor Syariah di Bank Muamalat Cabang Sungkono Surabaya “, (Surabaya: IAIN Ponorogo) h. 3738.

16 Julius R, Latumaerisa. 2013. Bank dan Lembaga Keuangan Lainnya, (Jakarta: Salemba Empat) h. 267

17 Amir, Letter of Credit, 3-4.

${ }^{18}$ Latumaerissa, Bank dan Lembaga, 267
} 
beserta syarat-syaratnya. Tanpa komponen-komponen ini tidak akan terjadi transaksi dan tanpa terpenuhinya syarat-syarat yang telah ditentukan, tentu saja transaksi tersebut tidak sah. Sedangkan komponen- komponen tersebut yang ada di dalam L/C Syariah adalah ${ }^{19}$ :

1) Aqid (pelaku transaksi)

Aqid adalah pelaku transaksi yang terdiri dari importir (pembeli), eksportir (penjual), opening bank, dan advising bank. Semua pelaku dalam transaksi ini sudah memenuhi syarat aqid. Importir dan eksportir telah memiliki ahliyah, sedangkan bank, baik opening maupun advising bank, telah diberi wilayah (wewenang).

2) Ma"qud alaih (objek transaksi)

Ma"qud alaih adalah objek transaksi yang berupa barang dagangan yang diperjualbelikan.

Objek transaksi ini harus memenuhi persyaratan yang telah ditentukan, diantaranya adalah harus berupa barang yang bermanfaat dan harus jelas spesifikasinya. Objek L/C harus bermanfaat dan tidak dilarang oleh syara. Oleh karena itu, jika objek dilarang oleh syara, seperti miras, dan lain-lain, maka secara otomatis L/C ini tidak sah/batal.

3) Mawdu al aqd (Tujuan transaksi)

Mawdu al aqd adalah maksud dilaksanakannya kontrak, tidak boleh bertentang dengan syara, karena maksud dan tujuan sangat bergantung kepada subyek pelaku kontrak. Jika diketahui bahwa ada transaksi L/C yang menyimpang dari syara seperti penipuan dengan membuka L/C fiktif, maka sudah jelas transaksi termasuk masuk ke dalam transaksi terlarang.

4) Sighah (Ungkapan transaksi)

Sighah adalah ungkapan transaksi atau ijab dan qabul. Sighah dalam L/C terjadi secara lisan dan diperkuat dengan bukti tertulis dalam bentuk dokumen.

a) Dokumen Letter of Credit $(L / C)$

Dalam L/C terdapat syarat dan kondisi dokumen yang diminta, dokumen-dokumen tersebut dapat dikelompokkan dalam ${ }^{20}$ :

1) Dokumen Utama, yaitu dokumen yang diterbitkan untuk alat pembuktian realisasi ekspor meliputi:

a) Invoice atau faktur, yaitu berupa nota perhitungan untuk importir yang berisikan data mengenai barang.

b) Bill of lading, suatu dokumen bertanggal yang dikeluarkan oleh maskapai pengangkutan/ agennya/ nahkoda kapal sebagai pihak pengangkut.

\footnotetext{
${ }^{19}$ Prasetiyo, “Kontrak dan...”, hal. 3-4.

${ }^{20}$ Syarif Arif M, Petunjuk Praktis Perdagangan Luar Negeri, h. 18
} 
c) Asuransi atau pertanggungan, yaitu suatu perjanjian yang mana seorang penanggung mengikatkan kepada seseorang tertanggung.

d) Dokumen Pendukung, yaitu dokumen untuk memperkuat dan merinci hingga memperjelas hal-hal yang telah ada pada dokumen utama. Dokumen pendukung, antara lain:

1) Packing List, daftar yang berisikan rincian lengkap mengenai barang terdiri atas jumlah, jenis, dan satuan barang yang terdapat dalam setiap kemasan.

2) Weight note, nota timbangan yang berisikan rincian berat setiap peti atau kemasan, umumnya dalam rincian itu menerangkan berat kotor seluruh kemasan yang kemudian serta berat bersih yang dihimpun menjadi satu.

3) Measurement list, dokumen yang berisi daftar volume kubikasi setiap kemasan.

4) Inspection Certificate, adalah suatu pernyataan dan pihak yang ditentukan dalam L/C yang menyatakan bahwa: jenis barang, mutu, jumlah, harga, dan lainnya yang diminta $\mathrm{L} / \mathrm{C}$ telah sesuai.

5) Cheinical analysys, merupakan hasil pemeriksanaan laboratorium atas suatu barang.

6) Test certificate, yaitu sertifikat yang menerangkan kapasitas serta konstruksinya setelah dilakukan uji coba.

7) Manufacturs certificate, suatu sertifikat yang dibuat oleh produsen yang menyatakan bahwa barang-barang tersebut benar-benar hasil produksinya dengan merk dagang tertentu.

8) Certificate of origin, yaitu surat keterangan negara asal barang.

2) Dokumen Pelengkap ${ }^{21}$, yaitu dokumen-dokumen yang melengkapi keterangan yang diperlukan oleh petugas, operator yang akan mengoperasikan atau merekrut barang-barang yang diperdagangkan dalam transaksi ekspor impor. Dokumen ini terdiri dari:

a) Instructional manual, dokumen ini melengkapi keterangan berupa petunjuk kepad operator dalam mengoperasikan/cara menjalankan.

b) Layout schame, digunakan untuk barang berupa mesin-mesin sesuai urutan produksi.

c) Bro chure / leaflet, berupa buku kecil yang berisi petunjuk singkat mengenai suatu produk, di dalamnya terdapat informasi kepada konsumen tentang produk yang dimaksud.

d) Keuntungan dari Letter of Credit $(L / C)$ Pembayaran dengan menggunakan L/C sangat

\footnotetext{
${ }^{21}$ Ibid,h. 21.
} 
membantu memudahkan eksportir dan importir dalam melakukan transaksi. Banyak keuntungan yang diperoleh dari L/C diantaranya:

1. Kepastian membayar dan menghindari resiko. Dengan adanya L/C berarti merupakan jaminan bagi eksportir bahwa tagihannya pasti dilunasi bank sesuai ketentuan, reputasi atau nama baik bank yang membuka L/C merupakan jaminan pokok, dimana resiko untuk tidak dibayar sangat minim.

2. Penguangan dokumen dapat langsung dilakukan. Bila barang sudah dikapalkan, maka adanya L/C Shipping documents (surat-surat pengapalan) dapat langsung diuangkan, jadi tidak perlu lagi menunggu pembayaran atau kiriman uang dan importir.

3. Biaya yang dipungut bank untuk negosiasi dokumen relative kecil bila ada L/C.

4. Terhindar dari resiko pembatasan transfer valuta setiap pembukaan L/C Opening Bank sudah menyediakan valuta asing untuk setiap tagihan yang didasarkan pada $\mathrm{L} / \mathrm{C}$ tersebut.

5. Kemungkinan memperoleh uang muka atau kredit tanpa bunga bila importir bersedia membuka L/C dengan syarat "Red Clouse" maka eksportir dapat memperoleh uang muka dan L/C yang tersedia, ini berarti eksportir mendapat kredit tanpa bunga atau semacam uang panjar yang biasanya diberlakukan untuk memulai produksi barang yang akan diekspor.

e) Keuntungan bagi importir:

1. Pembukaan L/C dapat diartikan bahwa orang bank meminjamkan nama baik dan reputasinya kepada importir sehingga dapat dipercayai eksportir. Eksportir yakin bahwa garansi yang akan dikirim pasti akan dibayar.

2. L/C merupakan jaminan bagi importir bahwa dokumen atas barang yang dipesan akan diterimanya dalam keadaan lengkap dan utuh. Karena akan diteliti oleh bank yang sudah mempunyai keahlian dalam hal itu.

3. Importir dapat mencatumkan syarat-syarat untuk pengamanan yang pasti akan dipatuhi oleh eksportir agar dapat menarik uang L/C yang tersedia.

Adapun manfaat dari adanya transaksi L/C Syariah diantaranya adalah ${ }^{22}$ :

a. Bagi Bank

1) Sumber pendapatan dalam bentuk imbalan/ fee dari akad wakalah bil ujrah dan kafalah.

2) Sumber pendapatan dalam bentuk bagi hasil dari akad wakalah bil ujrah dan

${ }^{22}$ Nur Hikmah, Skripsi: "Studi Komparasi Produk Letter of Credit (L/C) Pada Bank Konvensional dan Bank Syariah”, (Semarang: UIN Walisongo, 2018, h.23-24. 
mudharabah.

3) Sumber pendapatan dalam bentuk imbalan dari wakalah bil ujrah dan hawalah.

a. Bagi Nasabah

1) Menerima barang yang diimpor disertai dokumen pendukung yang sesuai.

2) Memperoleh jasa penyelesaian pembayaran dan atau penjaminan.

3) Akseptasi yang mendukung aktivitasnya dalam perdagangan internasional ${ }^{23}$.

Fungsi dari Letter of Credit $(L / C)$

1. Sebagai alat pembayaran, L/C memberi rasa aman kepada penerima serta dapat dilaksanakan jika semua dokumen yang diminta telah dipenuhi penerima.

2. Sebagai alat penjamin, L/C memberikan rasa aman kepada pihak terjamin. Serta dapat dilaksanakan jika pelaksanaan kontrak dasar yang dijamin L/C tidak dapat dilakukan pihak yang dijamin ${ }^{24}$

\section{Jenis-Jenis Letter of Credit $(L / C)^{25}$}

Penyelesaian transaksi antara eksportir dan importir dalam letter of credit sangat tergantung dari jenis letter of credit nya, adapun jenis-jenis letter of credit antara lain:

1) Revocable letter of credit, yaitu letter of credit yang setiap saat dapat dibatalkan atau diubah secara sepihak oleh bank pembuka (opening bank) tanpa pemberitahuan terlebih dahulu.

2) Irrevocable letter of credit, yaitu letter of credit yang tidak dapat dibatalkan atau diubah tanpa persetujuan dari semua pihak yang terlibat ${ }^{26}$

3) Sight letter of credit,yaitu letter of credit yang syarat pembayarannya langsung pada saat dokumen diajukan oleh eksportir kepada advising bank.

4) Usage letter of credit, merupakan letter of credit yang pembayarannya baru dilakukan dengan tenggang waktu tertentu, misalnya 1 bulan dari pengapalan barang atau 1 bulan setelah penunjukkan dokumen.

5) Restricted letter of credit, L/C yang cara pembayarannya hanya batas kepada bank- bank tertentu yang namanya tercantum dalam letter of credit.

6) Red clause letter of credit, yaitu L/C di mana bank pembuka L/C memberi kuasa kepada bank pembayar untuk membayar uang muka kepada beneficiary sebagian tertentu atau

\footnotetext{
${ }^{23}$ Muhamad, Manajemen Dana, (Jakarta:Raja Grafindo Persada, 2014), hal. 59.

${ }^{24}$ Ramlan Ginting, Letter of Credit Majalah Aspek Hukum dan Bisnis

${ }^{25}$ Selfia Anggraeni. 2017. Skripsi: “Implementasi Fatwa Dewan Syariah Nasional No.34 dan No.35 Tentang Letter of Credit Impor-Ekspor Syariah di Bank Muamalat Cabang Sungkono Surabaya “, (Surabaya: IAIN Ponorogo) h.3840

${ }^{26}$ Arthesa, Bank dan Lembaga, 95.
} 
seluruh nilai L/C sebelum beneficiary menyerahkan dokumen.

7) Transferable letter of credit, yaitu L/C yang memberikan kepada beneficiary untuk memindahkan sebagian atau seluruh nilai L/C kepada satu atau beberapa pihak lainnya.

8) Revolving letter of credit, yaitu L/C yang penggunaannya dapat dilakukan secara berulang-ulang.

9) Back to back letter of credit, yaitu L/C yang memberikan hak ke penerima L/C untuk membuka L/C kembali dengan menjaminkan L/C yang diterimanya.

10) Standby letter of credit, yaitu L/C yang bersifat jaminan atau bank garansi yang dikeluarkan oleh pihak di negara asing untuk menjamin pinjaman yang dilakukan oleh perusahaan lokal ${ }^{27}$

Proses Pembukaan Letter of Credit $(L / C)^{28}$

Proses pembukaan L/C dimulai dengan penandatanganan kontrak penjualan antara penjual dan pembeli. Berdasarkan kontrak penjualan tersebut pembeli memohon kepada bank penerbit untuk menerbitkan L/C kepada penjual sebagai alat pembayaran untuk membayar barang yang akan diekspor oleh penjual kepada pembeli. Bank menyediakan beberapa formulir di mana pembeli harus melengkapi dan menandatanganinya. Formulir tersebut antara lain berisi suatu permohonan dan pembeli kepada bank untuk membuka suatu L/C untuk kepentingan penjual.

Salah satu formulir yang berhubungan dengan pembukaan tersebut, yang biasanya disebut syarat-syarat umum untuk pembukaan L/C, antara lain ${ }^{29}$ :

1) Adanya janji dan pembeli untuk membayar kembali kepada bank bilamana bank melakukan pembayaran lebih dahulu atas dokumen-dokumen yang diserahkan.

2) Persyaratan bahwa pembeli akan memberikan dokumen dengan dasar hak atas barangbarang kepada bank sebagai jaminan.

Langkah selanjutnya setelah formulir permohonan pembukaan L/C beserta formulirformulir lainnya diisi dan ditandatangani oleh pembeli dan disetujui oleh bank, kemudian bank berkewajiban menerbitkan L/C dengan dilengkapi syarat-syarat yang tercantum dalam formulir permohonan tersebut dan mengirimkannya kepada beneficary langsung atau melalui bank koresponden atau cabangnya.

Berikut skema tentang proses dan prosedur mengenai transaksi ekspor impor dengan pembiayaan L/C:

\footnotetext{
${ }^{27}$ Kasmir, Manajemen Perbankan (Jakarta: Rajawali Pers, 2012), 144-145.

${ }^{28}$ Heni Purwati, Skripsi: “Aplikasi Pembiayaan Ekspor Impor Melalui Letter of Credit (L/C) di Bank Mandiri Syariah Dalam Perspektif Islam”, (Surabaya: IAIN Sunan Ampel, 2009), h.42-44.

${ }^{29}$ Supriyo Andhibroto, Letter of Credit dalam Teori dan Praktik, h. 141.
} 


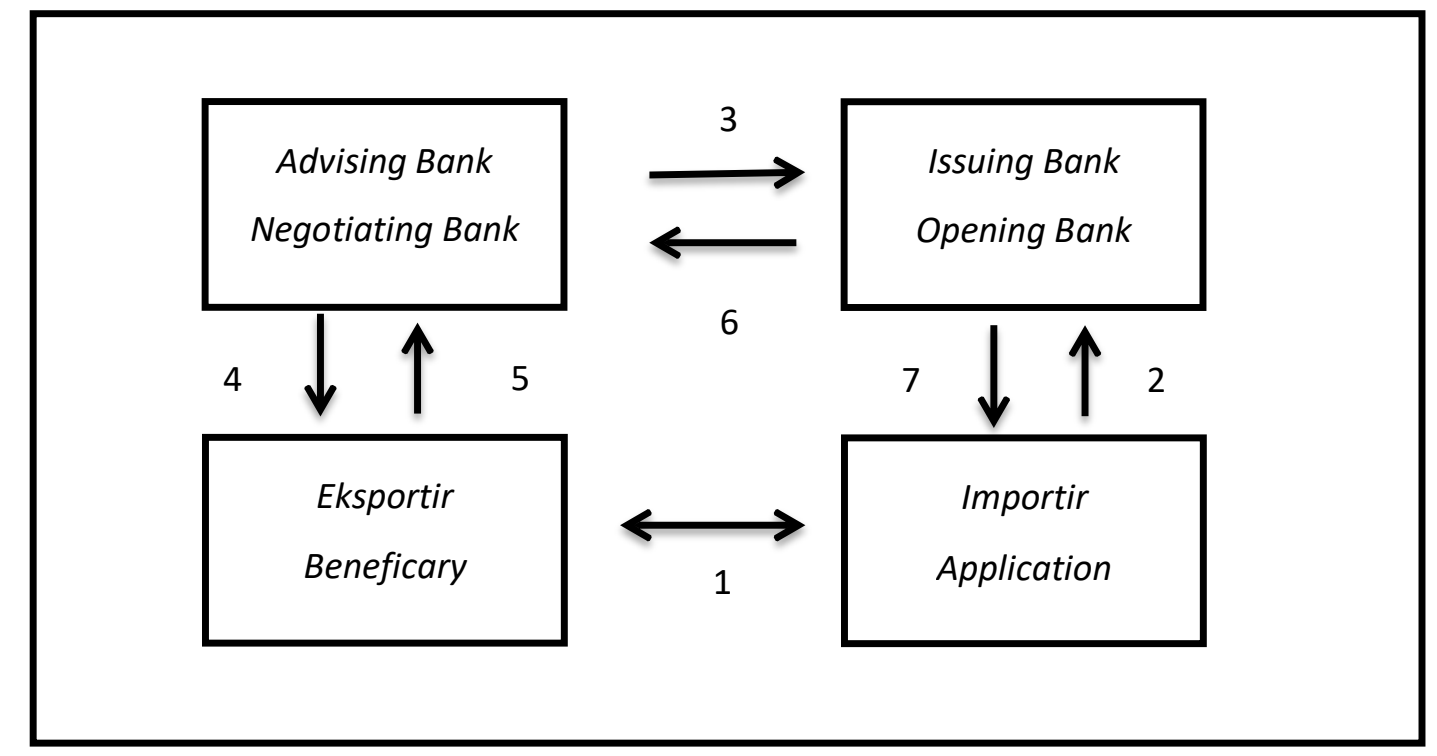

Keterangan:

1) Eksportir dan Importir mengadakan kontrak.

2) Importir mengajukan aplikasi ke bank pembuka L/C (Opening bank).

3) Opening bank membuka L/C ke bank penerus (Advising bank).

4) Advising bank meneruskan L/C kepada Eksportir.

5) Eksportir menyiapkan dokumen yang diperoleh dan maskapai pelayaran, instansiinstansi penerbit dokumen ke bank penegosiasi.

6) Bank penegosiasi mengirimkan dokumen ke bank pembuka.

7) Opening bank menyerahkan dokumen ke importir, mengkreditir rekening bank penegosiasi.

Selanjutnya setelah importir menerima dokumen dan bank penerbit, kemudian importir mengurus pengeluaran barang dan perusahaan pelayaran dan instansi-instansi terkait.

e) Prosedur Letter of Credit $(L / C)$ di Bank Mandiri Syariah ${ }^{30}$

Bank Mandiri Syariah mendefinisikan letter of credit sebagai janji tertulis berdasarkan permintaan tertulis nasabah (applicant) yang mengikat Bank Syariah Mandiri sebagai bank pembuka untuk membayar kepada penerima atau order-nya atau menerima dan membayar wesel pada saat jauh tempo yang ditarik penerima, atau memberi kuasa pada bank lain untuk melakukan pembayaran kepada penerima, atau untuk menegosiasikan wesel-wesel yang ditarik oleh penerima atas penyerahan dokumen.

Dalam mengajukan letter of credit terdapat beberapa prosedur yang ditetapkan oleh Bank

\footnotetext{
${ }^{30}$ Heni Purwati. 2009. Skripsi: "Aplikasi Pembiayaan Ekspor Impor Melalui Letter of Credit (L/C) di Bank Mandiri Syariah Dalam Perspektif Islam”, (Surabaya: IAIN Sunan Ampel) h. 49-52.
} 
Mandiri Syariah antara lain :

1. Harus memiliki rekening di Bank Syariah Mandiri.

2. Harus memiliki perizinan impor.

3. Mengajukan permohonan pembukaan L/C.

4. Supplier (beneficiary) harus berkedudukan di luar negeri.

5. Dibukakan line facility apabila dana jaminan nasabah tidak mengcover seluruh nilai $\mathrm{L} / \mathrm{C}$.

6. Dikenakan biaya komisi, biaya SWIFT dan handling document sesuai ketentuan Bank Syariah Mandiri.

Berdasarkan prosedur tersebut dapat diuraikan prosesnya dalam tahap-tahap sebagai berikut :

1. Negosiasi antara penjual/eksportir dan pembeli/importir (dalam hal ini antara perusahaan A dan perusahaan K) mengenai kesepakatan harga dan jenis barang;

2. Perusahaan mengajukan permohonan L/C ke Bank Mandiri;

3. Bank Mandiri mengadakan analisa terhadap permohonan tersebut;

4. Jika Bank menyetujui permohonan tersebut, maka bank dan pemohon L/C mengadakan perjanjian. Dalam hal ini, Bank Mandiri adalah bank yang menerbitkan L/C, maka sering disebut sebagai Bank Penerbit atau Issuing Bank atau Remitting Bank;

5. L/C diterbitkan melalui perantara yang ditunjuk atas dasar kesepakatan antara pembeli, penjual dan bank Mandiri;

6. Bank perantara meneruskan L/C yang diterima dari bank penerbit ke perusahaan $\mathrm{K}$. Bank perantara sering disebut sebagai Bank Penerus atau Advising Bank atau Negotiating Bank;

7. Setelah menerima L/C, perusahaan $\mathrm{K}$ kemudian mengirimkan barangnya kepada perusahaan A;

8. Perusahaan K membawa dokumen pengiriman barang kepada bank penerus untuk menagih pembayaran;

9. Bank penerus tidak langsung mengadakan pembayaran, namun sesuai fungsinya bank penerus meneruskan dokumen tersebut kepada bank Mandiri sebagai bank penerbit;

10. Bank penerbit meneliti keabsahan dokumen dan kesesuaian isi perjanjian jual beli serta $\mathrm{L} / \mathrm{C}$;

11. Apabila dokumen sesui, maka bank penebit melakukan pembayaran keperusahaan $\mathrm{K}$ 
melalui bank penerus;

12. Bank penerus meneruskan dan melakukan pembayaran pada perusahaan $\mathrm{K}$;

13. Bank penerbit menagih kewajiban pembayaran pembelian barang ke perusahaan A sebagai pembeli;

Syarat-syarat yang diberikan oleh Bank Mandiri Syariah umtuk pembukaan L/C Surat

Credit Berdokumen, yaitu:

a. Legalitas usaha / pendirian.

b. API (Angka Rengenal Importir) fungsi untuk monitoring.

c. Laporan keuangan.

d. Referensi bank yaitu keterangan importir pernah buka pembiayaan L/C berapa kali atau bukti pernah melakukan impor barang.

Selanjutnya mengenai mekanisme pembayaran:

1. Bank menerbitkan $\mathrm{L} / \mathrm{C}$ dalam rangka pembayaran transaksi import atas dasar permintaan importir yang diajukan kepada bank dengan mengisi formulir permohonan penerbitan L/C.

2. Bank hanya dapat mengubah $\mathrm{L} / \mathrm{C}$ atas dasar permintaan importir yang diajukan kepada bank dengan mengisi formulir permohonan perubahan L/C.

f) Realisasi Letter of Credit $(L / C)$ di Bank Mandiri Syariah

Realisasi letter of credit di Bank Mandiri Syariah berhubungan dengan hal yang menyangkut kewajiban dan tanggung jawab bank sebagai pihak yang berurusan dengan dokumen-dokumen mengenai mekanisme yang dipakai. Dan yang ditemukan pada Bank Mandiri Syariah mengenai proses Letter of credit dengan menggunakan skema transaksi yang islami, seperti musyarakah, mudharabah ataupun murabahah. Namun saat ini yang pernah digunakan oleh bank Mandiri Syariah adalah Letter of credit dengan menggunakan akad wakalah.

Oleh karena akad yang digunakan oleh Bank Mandiri Syariah dalam transaksi ekspor impor melalui letter of credit adalah wakalah maka bank hanya memperoleh pendapatan berupa fee saja atau jasa yang telah diberikan. Yaitu untuk pengurusan dokumen-dokumen transaksi impor, karena disini import memiliki dana sendiri.

Besarnya ujrah disepakati diawal perjanjian secara pasti dalam bentuk nominal bukan prosentase untuk menghindari adanya riba. Pada prinsipnya dalam transaksi letter of credit terdapat beberapa akad yang diatur secara islami seperti; musyarakah, murabahah, atau mudharabah. Namun apa yang ditemukan pada produk Bank Mandiri Syariah berupa letter of credit hanya menggunakan akad wakalah. 
Sedangkan pembiayaan menggunakan musyarakah, hal ini terjadi kalau jumlah biaya yang diberikan oleh nasabah atau importir dalam melakukan ekspor impor melalui letter of credit kurang dari yang ditetapkan. Maka dalam hal ini bank Mandiri Syariah memberikan pembiayaan berdasarkan prinsip syariah yaitu musyarakah.

Dalam pembiayaan ini juga terdapat kelebihan yang ditawarkan oleh Bank Mandiri Syariah yaitu: lebih menguntungkan karena berdasarkan prinsip bagi hasil dan mekanisme pengembalian yang fleksibel sesuai dengan realisasi usaha.

\section{Analisis Terhadap Aplikasi Pembiayaan Ekspor Impor melalui Letter of Credit $(L / C)$ di}

\section{Bank Mandiri Syariah}

Pada Bank Syariah, sebelum nasabah membuka L/C ia bisa memilih akad yang sudah disediakan oleh bank. Adapun akad-akad yang bisa digunakan dalam pelaksanaan L/C impor syariah antara lain adalah wakalah bil ujrah, wakalah bil ujrah dan qardh, murabahah, salam/ishtisna, wakalah bil ujrah dan mudharabah, musyarakah, serta wakalah bil ujrah dan hawalah. (footnote Fatwa Nomor 34/DSN- MUI/IX/2002 Tentang L/C impor Syariah) Pelaksanaan L/C ekspor syariah menggunakan akad wakalah bil ujrah, wakalah bil ujrah dan qardh, wakalah bil ujrah dan mudharabah, musyarakah serta al-ba" $i$ dan wakalah. ${ }^{31}$

Pada transaksi L/C impor syariah, Bank Syariah Mandiri berkedudukan sebagai issue bank. Akad yang digunakan oleh Bank Syariah Mandiri ketika nasabahnya menjadi pihak importir menggunakan akad murabahah. Karena menggunakan akad murabahah karena, maka bank akan memperoleh keuntungan. Sedangkan pada L/C ekspor Syariah, Bank Syariah Mandiri berkedudukan sebagai advising bank. Akad yang bisa digunakan oleh eksportir adalah akad wakalah bil ujrah. Karena menggunakan akad wakalah bil ujrah, maka bank akan mendapatkan ujrah / fee.

\section{KESIMPULAN}

Penerapan akad wakalah dalam perbankan antara lain transfer, kliring, inkaso, intercity clearing, letter of credit, dan payment. Dalam penerapan syariah tidak boleh melanggar aspekaspek yang dilarang dalam syariat Islam. Dalam hal ini Dewan Pengawas Syariah (DPS) harus terus mengawasi aktifitas perbankan untuk menjamin kesyariahan produk-produk bank syariah.

Pada transaksi L/C, Bank Syariah Mandiri berkedudukan sebagai issue bank. Akad yang digunakan oleh Bank Syariah ketika nasabahnya menjadi pihak importir menggunakan akad murabahah. Karena menggunakan akad murabahah, maka bank berhak untuk memperoleh

${ }^{31}$ Fatwa Nomor 35 /DSN-MUI/IX/2002 tentang L/C ekspor syariah 
keuntungan.

Sedangkan pada L/C ekspor Syariah, Bank Syariah berkedudukan sebagai advising bank. Akad yang bisa digunakan oleh eksportir adalah akad wakalah bil ujrah. Karena menggunakan akad wakalah bil ujrah, maka bank akan mendapatkan ujrah / fee. Dengan demikian bank berhak dan boleh mendapatkan keuntungan atas effort yang telah dikeluarkan bank dalam mengakomodir kebutuhan nasabah.

\section{DAFTAR PUSTAKA}

Anggraeni, Selfia. 2017. Implementasi Dewan Syariah Nasional No.34 dan No.35 Tentang Letter of Credit Impor Ekspor Syariah di Bank Mu"amalat Cabang Sungkono Surabaya. Skripsi. Tidak Diterbitkan. Fakultas Syariah. IAIN Ponorogo: Surabaya. Antonio, M. Syafi'i. 2001. Bank Syariah dari Teori ke Praktik. Jakarta: Gema Insani.

Darsono, dkk. 2017. Perbankan Syariah di Indonesia. Depok: Rajawali Pers.

Devita, Irma. 2010. Letter of Credit (L/C) Impor Syariah. Diakses pada Selasa, 05 November 2019. https://www.google.com/amp/s/irmadevita.com/amp/2010/letter-of-credit-lcimpor- syariah.

Fatwa DSN-MUI No.10/DSN-MUI/IV/2000 Tentang Wakalah.

Fatwa DSN-MUI No.113/DSN-MUI/IX/2017 Tentang Akad Wakalah bil-Ujrah.

Fatwa DSN-MUI No. 34/DSN-MUI/IX/2002 Tentang Letter of Credit (L/C) Impor Syariah. Fatwa

DSN-MUI No. 35/DSN-MUI/IX/2002 Tentang Letter of Credit (L/C) Ekspor Syariah Hikmah, Nur. 2018. Studi Komparasi Produk Letter of Credit (L/C) Pada Bank Konvensional dan Bank Syariah. Skripsi. Tidak Diterbitkan. Fakultas Syariah dan Hukum. UIN Walisongo: Semarang.

Ismail. 2011. Perbankan Syariah. Jakarta: Kencana Media Group.

Mubarok, Jaih, dan Hasanudin. 2017. Fikih Muamalah Maliyyah (Akad Syirkah dan Mudharabah). Bandung: Simbiosa Rekatama Media.

Nuhyatia, Indah. 2013. Penerapan dan Aplikasi Akad Wakalah Pada Produk Jasa Bank Syariah. Economic: Jurnal Ekonomi dan Hukum Islam, Vol. 3, No. 2.

Purwati, Heni. 2009. Aplikasi Pembiayaan Ekspor Impor Melalui Letter of Credit (L/C) di Bank Mandiri Syariah Dalam Perspektif Hukum Islam. Skripsi. Tidak Diterbitkan. Fakultas Syariah. IAIN Sunan Ampel: Surabaya. 